\title{
IAMJ
}

INTERNATIONAL

AYURVEDIC

MEDICAL JOURNAL

ISSN: 2320-5091

Impact Factor: 6.719

\section{CONCEPT OF RASAYANA IN MANAGEMENT OF STHOULYA}

\author{
$\underline{\text { Jayashree Gunjigonvi }}^{1}$, Prasan V Joshi $^{2}$
}

${ }^{*} 2^{\text {nd }}$ year P.G Scholar, Department of PG Studies in Kayachikitsa, S.V.M. Ayurvedic Medical College, Ilkal, Karnataka, India

${ }^{2}$ Professor and H.O.D. Department of PG Studies in Kayachikitsa, S.V.M. Ayurvedic Medical College, Ilkal, Karnataka, India

\section{Corresponding Author:jayag2037@gmail.com}

\section{https://doi.org/10.46607/iamj1 809092021}

(Published Online: August 2021)

Open Access

(C) International Ayurvedic Medical Journal, India 2021

Article Received:04/08//2021 - Peer Reviewed:23/08/2021 - Accepted for Publication:24/08/2021

\section{Check for updates}

\begin{abstract}
Immunity is a protective mechanism of the body; weak immunity may give rise to so many health conditions. The immunity of the person cannot be defined by personal appearance, as a lean body person may have stronger immunity compared to an obese person. The immunity depends upon proper nourishment of body tissues and lack of proper nourishment leads to a decrease in the person strength and lifespan. Sthoulya is one of the conditions where there is increased nourishment of only Medadhatu with lack of nourishment of other Rasadidhatu which further give rise to so many complications. Rasayana is one of the peculiar concepts of Ayurveda known for its Rejuvenation, Immunebooster, and antioxidant properties. As the name itself suggests it is the procedure with specific dravyas for the nourishment of Rasadidhatu. In Sthoulya as it is vruddi (Increased) of Shleshma, Vatadosha and Medadhatu with lack of nourishment of other dhatu occur so the use of Dravya having Rasayana, shleshmahara, Medohara and Vatagna properties are more beneficial.
\end{abstract}

Keywords: Rasayana, Sthoulya, Shleshmahara, Medohara, Vatagna 


\section{INTRODUCTION}

Sthoulya is one of the Medoroga and it is Kaphajananatmajavyadhi. ${ }^{1}$ It is defined as "chala sphik udara stana" which is the pendulous movement of the Buttock, Abdomen and breast region, here a person looks stouty but may not have sufficient physical strength and activity. ${ }^{2}$ As per modern aspect Sthoulya can be compared to obesity which is defined as it is excess adipose tissue mass or grossly fat. The prevalence of obesity is increasing worldwide in all age groups within people of higher socioeconomic status, especially in urban communities.

\section{Causes for Sthoulya: ${ }^{3}$}

Aharaja Nidan: Atisampoorana (Eating excess quantity of food), eating Guru (Heavy), Madhura (Sweet), Sheet (Cold), Snigda (fatty food), Shleshmalaahara.

Viharaja Nidan: Avyayama (Lack of exercise), Avyavaya (Lack of sexual activities), Deevaswapna (Day sleep), Nityaharsha (Always being happy), Achinta (No worry)

Other Nidan: Beejaswabhava(Hereditary)

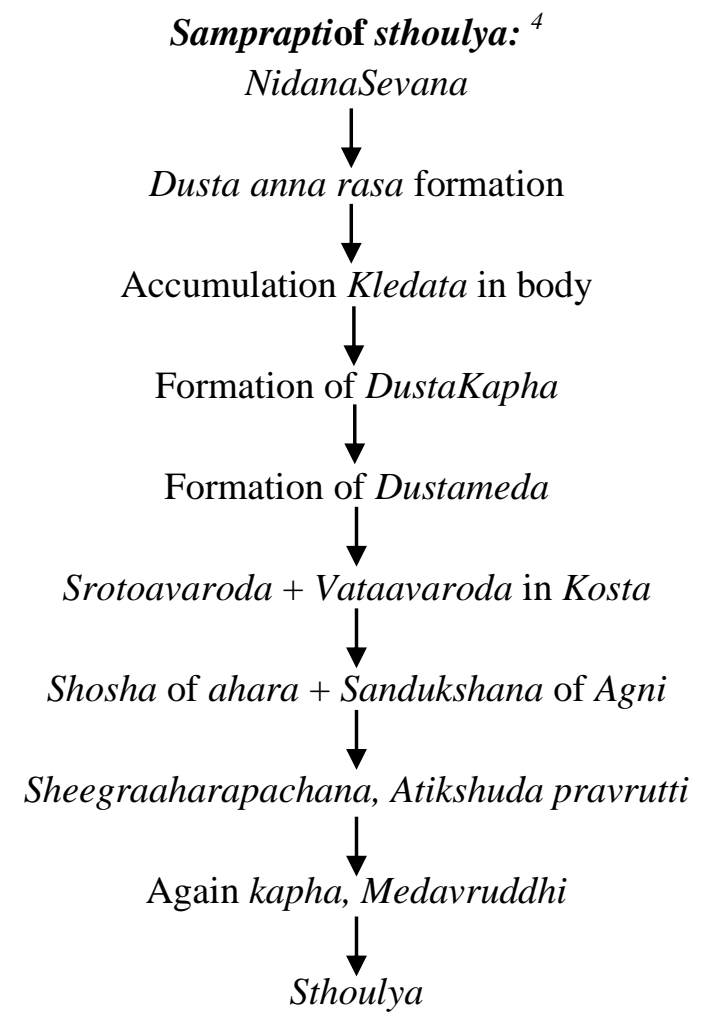

\section{Clinical manifestation of Sthoulya:}

Acharya Vagbhata mentioned three stages of Sthoulya, which are Heena sthoulya, Madya sthoulya, Ati sthoulya to plan the treatment. From the initial stage of Sthoulya, the person starts to face many problems these are explained by Acharya Chraka as an Astadosha ${ }^{5}$ and by other Acharyas as a disease to summarize them:- In the initial stage when a person starts to consume Kaphavruddikara ahara, a person starts to feel Angagourava (Heaviness in the body), Alasya (Laziness), Atinidra (Excessive sleep),
Tandra (Lethargic) etc., because of accumulation of Kapha and Kledata in body and when Meda start to accumulate in places then it leads to pendulous movement of Abdomen, buttock and breast region and increased sweat, during this time as there is only nourishment of Medadhatu not others Dhatu patient strength, longevity will start to decrease. When Vatavruddi occurs because of avarodha by Kapha, meda than kshaya of Rasadi dhatu other than Meda dhatu will occur so person starts to feel increased Kshuda (Appetite), Trishna (Thirst) which further 
leads to increased intake of food which further causes Sthoulya. As Medavruddi leads to obstruction of Srotas, the person suffers from Dourbalya, Kshudrashwas, Kruchravyavaya, Alpashukrata, Alpaprana etc.

Chikitsa: ${ }^{6}$

Sthoulya is a Santarapanajanya Vyadhi so the use of Guru (Heavy) and Atarpana Dravya (NonNourishing) along with Vatagna, Shleshmamedohara dravyas is indicated along with Tikshabasti, Rukshaudwartana and Shamanaoushadhi.

\section{Rasayana:}

Rasayana is one of the peculiar concepts of Ayurveda. Rasayana is a procedure with specific dravyas to nourish Rasadidhatu also which helps to attain Prashastaavastha (Excellence) of dhatu. ${ }^{7}$ Rasayana darvyas are used for two purposes that are Swastasya urjaskara (which enriches the quality of health) and Rogaprashamana (Curative). The benefits of Rasayana is, it prevents Akaala Jara (Premature ageing) and act as Vyadhishamaka (Curative), Vyadhipratibandaka (preventive) ${ }^{8}$ and proper use of Rasayanadravyas help to provide Deergayu (Longevity) and increases smruti (Memory), medha (Intelligence), Arogya (Health), vaya (Age), Prabha (Luster), varna (Colour), Swara (Voice), dehaindriyabala (Strength to both body and Indriya), vaksiddi (Whatever person says it will happen), kanti and help to attain prashastha avastha of dhatu (Excellence of Dhatu). Rasayana dravyas have effect on both Agni and Srotas. In Sthoulya Excess medadhatu will obstruct Rasadivaha srotas so Rasadi dhatu will not get proper nourishment except Medadhatu hence use of dravyas which are having Properties of Rasayana, Vatagna, Shleshmahara and Medohara will help to boost immunity, removes obstruction of other srotas so that all dhatu will get proper nourishment hence person easily overcome Sthoulya and its other complications like Astadosha and other diseases.

Role of Shodhana before using Rasayana: In Sthoulya person Shodanakarma is necessary, before administering any of Rasayanadravya as Shodana helps to remove Amadosha and it helps to keep Agni in its Prakrutaavastha (Normal state) and does Srotoshodana. Vamana karma may be beneficial as it reduces both Kapha and Meda hence adding more benefit to treatment.

\section{Details of Rasayana dravyas useful in Sthoulya person:}

\section{1) Guduchi (Tinosphora cordifolia)}

Guduchi has katu, tikta rasa, Madhura vipaka, Usna virya and act as Rasayana, Balya, Agnideepaka, Tridoshahara ${ }^{9}$ and medoshoshana. ${ }^{10}$ Katu rasa has deepana, kleda, sneha, medashoshana gunas along with it has Vayu and Agni mahabhuta which are opposite of mahabhuta of Kapha that is Pritvi and Jala mahabhuta thus it helps in reducing the excessive accumulation of Meda dhatu. Tikta rasa has deepana, shodhana, kleda, medashoshana property and it has Vayu and Akash mahabhuta, because of it tikta rasa of Guduchi cause laghuta in the body as both mahabhuta have laghu property and because of meda, kleda shoshana property they stop accumulation meda dhatu. Madhura vipaka of Guduchi act as Rasayana, and this Rasayana guna of Guduchi help to nourish Rasadi dhatu. Studies were done on Rats fed with a high-fat diet and Guduchi shows effectiveness in managing the body weight of rats than those Rats only fed with a high-fat diet. Another study done on Rats shows that it has antioxidant activity ${ }^{11}$ also study done on Drosophila melanogaster shows an increase in the lifespan in both parent and F-1 generation hence proving Rsayana property of Guduchi. As Guduchi is having both Rasayana property and sneha, kleda, medashoshana property it nourishes Rasadidhatu but reduces kledata, Medadhatu and because of its Tridoshahara property it balances Vata kapha and Balya property of it helps to Sthoulya person overcome Dourbalyata (Lethargic).

\section{2) Triphala:}

One of the important Rasayana Dravya in Ayurveda is Triphala consisting of Amalaki, Bibhitaki and Haritaki having Rasayana property nourishes Rasadhi dhatus delays the ageing process. $^{12}$ According to Acharyas Triphalachurna (Powder) taken with Madhu act as Atisthoulyahara ${ }^{13}$ also it has 
good immune modulator property, antioxidant property and reduces cholesterol which is attributed to the presence of flavonoids, alkaloids, tannins, saponin, glycosides and phenolic compounds and various studies were done on Triphala shows it the action of Cholesterol reduction. Triphala having Rasayana, Medahara property it Nourishes Rasadi dhatu except Medadhatu as it has Medahara property, and it balances Vatakapha dosha by its Tridoshahara property.

\section{3) Madhu (Honey):}

Madhu is the most appreciated and valued natural product introduced to humankind. Madhu pacifies all three vitiated doshas bytheir multiple actions and their qualities that is Madhura Rasa, Kasaya uparasa, Ruksha guna, Sheeta virya, Madhura vipaka and act as Sukshmamargaanusari (ability to permeate in microchannel) by its Prabhava. Madhura rasa gives nutrition to the tissue while Kasaya rasa provides lekhana karma and Ruksha guna of Madhu will make sthoulya person to krusha by its karshan property. Acharya Sushruta mentioned in Rasayana concept Madhu taken with water act as Rasayana that means it nourishes rasadhi dhatu so act as Vayasthapana $^{14}$ and again Madhu taken with lukewarm water act as Medohara ${ }^{15}$ (Reduces Meda), also Madhu is one among Nityapatya dravya. ${ }^{16}$ Madhu being Good Rasayana as well as potential antiobesity agent and it is Vayasthapaka dravyas it can be used to treat Sthoulya person and to treat other complications of Sthoulya.

\section{4) Shilajatu:}

Shilajatu is one of the herbomineral dravya and it has properties like Tikta, Katu, Kasaya rasa, Katu vipaka, Usna virya ${ }^{17}$ also it has properties like Rasayana and Vrishya. Shilajatu acts on Agni (Maintain the normal state of Agni) and Srotas (Removes the obstruction of srotas) which help to nourish rasadi dhatu. By its Katu vipaka and Ushna virya it reduces Kapha, Meda and kledata of the body so that Shilajatu took along with Agnimanth Swarasa act as Sthoulyahara ${ }^{18}$ thus it shows that Shilajatu will do dustameda ksaya Moreover the Rasayana property of Shilajatu Nourishes Rasadhidhatu. Shilajatu
Nourishes Rasadi dhatu by removing obstruction of srotas helps to keep the body tissue in a healthy state and improves the metabolism at every level of Dhatu thus delays the ageing process also. One line says about Shilajatu that is "which conqueror of mountains and destroyer of weakness" it has properties of dehadardyakara (Strength the body) and give Deergayu. ${ }^{19}$

\section{5) Guggulu:}

Guggulu has Katu Tikta Kasaya rasa,Katu vipaka, Usnavirya also Purana (Old) Guggulu has Laghu, Ruksa, Sukshma, Sara Guna (Qualities) and Nava (New) Guggulu has Snigdha, Picchila Gunas with Tridoshahara, Balya, Agnideepana, Swarya, Rasayana, Medahara (Old), Kledahara, Vrushya (New) action. ${ }^{20}$ Purana Guggulu having Usnavirya, Ruksha, Sukshama, Sara guna it Removes Avaroda (Obstruction) Of Srotas and helps to proper Nourishment of Dhatu and as it has Agnideepana and Rasayana, Medahara Property it Brings Agni to its Normal state and helps to Nourishment of Rasadi dhatu except Medadhatu. Guggulu shows Antihyperlipidemic, Antioxidant, anti-inflammatory, immunomodulatory, and appetite-regulating activities due to its chemical compounds. In Sthoulya as there is Vatakapha dosha is in increased and Increased Medadhatu is the main culprit to Sthoulya person to experience Dourbalya, Dourgandya, Ayurhrasa, Javoparoda and soon Because of Guggulu Tridoshhara, Kledahara, Agnideepana, Rasayana and Medahara property Guggulu Rasayana will be very beneficial to Sthoulya person.

\section{6) Loharasayana: ${ }^{21}$}

Loharasayana is one of the best Medohara because it contains Guggulu, Tiphala, Talamuli and so many potent drugs. Loharasayana has the properties like Vata shleshmahara, Rasayana, Medhavardaka, Uttam Vajikarana, Kantikaraka, and helps to Conceive by acting on Virya and Rajodosha. The dose instructed to take is 1 Karshamatra after a person undergone Shodhana. While taking Loharasayana intake of dravyas like Kadalikanda, Kanji, Karamarda, Karira, Karavellaka should be contraindicated. The properties like Rasayana help to 
nourish all the dhatus except Medadhatu because of Medahara Property as the line says about Loharasayana that is it Scrapes medavraddi of Kukshipradesha (Hip region) of the person to the extent that it reaches Patal (Deep region) and it combats Vaatashleshmavruddi by Vatashleshma shamana because of it Srotoavaroda will be removed and proper nourishment to person body occur which makes him healthy. Again it has uttam vajikarana and removes virya, rajodosha property which helps Sthoulya person suffering from klaibyata(Infertility), because of all these properties Loharasayana is one of the best Rasayana dravya to treat Sthoulya condition and its complications.

\section{7) Trayushanadya loha: ${ }^{22}$}

Trayushanadya loha is considered Uttam Rasayana in the classic textbook. It contains lohabhasma and other thirteen drugs it. The dose of it is 1 Masha along with Madhu and Ghrita. It actions mentioned are it scrapes Medavraddi of Sthoulya person and it increases Agni, Bala, Varna of person. The properties of Trayushandya loha helps in Sthoulya person to reduce Dustamedadhatu and normalizes Agni and makes person Balya and Rasayana property will nourish other dhatu which make a person to healthy to combat other complications of Sthoulyata and other opportunistic diseases.

\section{8) Bhallataka Kshoudra: $:^{23}$}

Bhallataka Kshudra is one of the Rasayana Yoga mentioned in classics, contains Bhallataka, Madhu and Ghrita. Bhallataka is known for its Kaphana and medagna property and because of its Tikshna, Usna guna it acts as Srotoshodaka. Madhu having lekhana and Roukshya guna does Karshana of Medadhatu and Ghrita has Properties of Vatapitta hara simultaneously it will not increase Kapha, and it nourishes Rasa Shukra dhatu. Observing all the properties, Bhallataka Kshoudra Rasayana can be used in Sthoulya person.

9) Achara Rasayana: ${ }^{24}$

Achara Rasayana is one of the behavioral therapies in Ayurveda for good health. For Sthoulya person two practices of Achara rasayana will help, among that one practice is Sama Jagarana - Swapna (maintain a balance between waking and sleeping cycle) this practice help person to keep his metabolic rate good and another Practice is Nitya Ksheeraghritaashinah (daily intake of milk and Ghee in diet with moderation) as Cowmilk has jeevaniya, Rasayana ${ }^{25}$ properties and Ghee is having Vatapittahara but not Shleshmavardhana (does not increase Kapha) property and nourishes Rasa, Shukradhatu and gives Bala to person and it rises healthy cholesterol of person that is HDL hence taking ghee and milk daily in diet with moderation is beneficial to Sthoulya person.

\section{DISCUSSION}

In Ayurveda Samprapti Vighatana Chikitsa will play a major role in treatment. In the Sthoulya condition, the involvement of Kapha, Meda, Vata, Srotoroda and Vikruta Agni all takes place Gradually so using Rasayana dravyas by observing different Avastha of sthoulya is more beneficial. Taking Guduchi swarasa in the morning with an empty stomach may be beneficial to reduce the initial stage of sthoulya that is when there is an accumulation of kledata, and Kapha is starting and the patient started to feel alasya, angagourava, as it reduces kledata in the body and reduces medadhatu and its rasayana property, will make sure that other rasadi dhatu will get proper nourishment so that person become healthy and energetic. Triphala Rasayana can be used when there is an increase of kapha, Vata and meda start, it will reduce dustameda by its compounds like flavonoids, Tannins, Glycosides etc and by its tridoshara it controls Vata and kapha and with Rasayan property it nourishes Rasadi dhatu. Triphala rasayan has properties like Vayastapana and vrishya which help sthoulya person suffering from Klaibyata, Kruchravyavaya, and Ayurhrasa. Madhu having qualities like Rukshata, lekhana and Karshana property so it can be used when a person having an accumulation of Kapha, Meda, Srotoavaroda and Agnivardhana (Because of its Roukshya guna it does don't increase Agni). Shilajatu Rasayan has properties like Rasayana, Medahara, Vrushya, Dehadaryakara, balya and Vayastapana so 
it can be used when there is an accumulation of Kapha, meda dhatu with there is no increased also it can be used to treat sthoulya person suffering from Dourbalya, Klaibyata, so it helps a person have a healthy long life. Guggulu And Bhallataka kshoudra can be used when there is more accumulation of dustameda because of their properties they will do karshana of dustameda. Achara rasayana is a lifestyle modification Sthoulya person need to adopt it in his lifestyle for better health.

\section{CONCLUSION}

Rasayana Dravyas are used to attain Prashsasta avastha of Rasadi dhatu that is the excellence of Dhatu. Rasayana Dravyas are misbelieved that they do only Bruhmana effect, but they help to increase Dhatus qualitatively not only quantitatively there are some Rasayana yogas which does Karshana along with so many other benefits like Balya, Vayasthapana Vrushya. In Sthoulya after shodanakarma, proper selection of dravyas is necessary. Selection of Rasayana dravyas having Vatashleshmahara, Medahara property along with other properties has more beneficial to treat sthoulya and its other complications. Rasayana dravyas should not be administered to Atisthoulya person because in Atishoulya person Shodhana is contraindicated.

\section{REFERENCES}

1. Vd. Harish Chandra Singh Kushawaha. Charakasamhita Vol. I (Sutra, Nidan, Viman, Shrira and Indriyasthana). Varanasi; Chaukambha Orientalia; 2018. p.305.

2. Vd. Harish Chandra Singh Kushawaha. Charakasamhita Vol. I (Sutra, Nidan, Viman, Shrira and Indriyasthana). Varanasi; Chaukambha Orientalia; 2018. p.310.

3. Vd. Harish Chandra Singh Kushawaha. Charakasamhita Vol (Sutra, Nidan, Viman, Shrira and Indriyasthana). Varanasi; Chaukambha Orientalia; 2018. p.309.

4. Vd. Harish Chandra Singh Kushawaha. Charakasamhita Vol. I (Sutra, Nidan, Viman, Shrira and Indriyasthana). Varanasi; Chaukambha Orientalia; 2018. p.310.
5. Vd. Harish Chandra Singh Kushawaha. Charakasamhita Vol.I (Sutra, Nidan, Viman, Shriraand Indriyasthana). Varanasi; Chaukambha Orientalia; 2018. p.309.

6. Vd. Harish Chandra Singh Kushawaha. Charakasamhita Vol.I (Sutra, Nidan, Viman, Shrira and Indriyasthana). Varanasi; Chaukambha Orientalia; 2018. p.313.

7. Vd. Harish Chandra Singh Kushawaha. Charakasamhita Vol.II (Sutra, Nidan, Viman, Shrira and Indriyasthana). Varanasi; Chaukambha Orientalia; 2018. p.2.

8. Dr G. Prabhakar Rao.Sharangadhara Samhita. First editionNew Delhi; Chaukhambha publication; 2013.p.18.

9. Dr. Bulusu Sitaram. Bhavaprakash Vol. I. Varanasi; Chaukamba Orientalia; 2020.p.229.

10. Dr S.D. Kamat. Danwantari nigantu. Varanasi; Chaukhamba Sanskrit Pratishthan; 2002.p.1.

11. Agarwal A, Malini S, Bairy KL, Rao MS. Effect of Tinosphora cordifolia on learning and memory in normal and memory defect rats.Indian Journal of Pharmacology.2002; Volume 34: p.339-349.

12. Vd. Harish Chandra Singh Kushawaha. Charakasamhita Vol.II (Sutra, Nidan, Viman, Shrira and Indriyasthana). Varanasi; Chaukambha Orientalia; 2018. p.34.

13. Dr. Nirmal Saxena. Vangasena Samhita. First edition. Vol.I. Varanasi; Chowkambha Sanskrit series; 2004.p.588.

14. Acharya YT. Susruta Samhita by Susruta with Nibandhasangraha teeka of Dalhanacharya, Varanasi. Chaukambha Sanskrit Sansthan; Reprint 2013.p.499.

15. Dr. Nirmal Saxena. Vangasena Samhita. First edition. Vol.I. Varanasi; Chowkambha Sanskrit series; 2004.p.589.

16. Vd. Harish Chandra Singh Kushawaha. CharakasamhitaVol.I(Sutra, Nidan, Viman, Shrira and Indriyasthana). Varanasi; Chaukambha Orientalia; 2018. p.72.

17. Acharya YT. Susruta Samhita by Susruta with Nibandhasangraha teeka of Dalhanacharya, Varanasi. Chaukambha Sanskrit Sansthan; Reprint 2013.p.456.

18. Vd. Harish Chandra Singh Kushawaha. Charakasamhita Vol.I (Sutra, Nidan, Viman, Shrira and Indriyasthana). Varanasi; Chaukambha Orientalia; 2018. p.313.

19. Vd. Harish Chandra Singh Kushawaha. Charakasamhita Vol.II (Sutra, Nidan, Viman, Shrira 
and Indriyasthana). Varanasi; Chaukambha Orientalia; 2018. p.35.

20. Dr. Bulusu Sitaram. Bhavaprakash Vol. I. Varanasi; Chaukamba Orientalia; 2020.p.202.

21. Dr. Nirmal Saxena. Vangasena Samhita. First edition. Vol.I. Varanasi; Chowkambha Sanskrit series; 2004.p.590.

22. Vd. Shrilaxmipatishastri. Yogaratnakar.Varanasi; Chaukambha Prakashan; 2013.p.99.

23. Vd. Harish Chandra Singh Kushawaha. Charakasamhita Vol.II (Sutra, Nidan, Viman, Shrira and Indriyasthana). Varanasi; Chaukambha Orientalia; 2018. p.43.

24. Vd. Harish Chandra Singh Kushawaha. Charakasamhita Vol.I (Sutra, Nidan, Viman, Shrira and Indriyasthana). Varanasi; Chaukambha Orientalia; 2018. p.438.

25. Vd. Harish Chandra Singh Kushawaha. Charakasamhita Vol.I (Sutra, Nidan, Viman, Shrira andIndriyasthana). Varanasi; Chaukambha Orientalia; 2018. p.201.

\section{Source of Support: Nil Conflict of Interest: None Declared}

How to cite this URL: Jayashree Gunjigonvi \& Prasan V Joshi: Concept Of Rasayana In Management Of Sthoulya. International Ayurvedic Medical Journal \{online\} 2021 \{cited September 2021\} Available from: http://www.iamj.in/posts/images/upload/2050_2056.pdf 